when it comes to knowledge of and attitudes about best management practices.

We examined the following specific research questions:

\title{
The impact of gender on agricultural conservation knowledge and attitudes in an lowa watershed
}

\section{C.G. Druschke and S. Secchi}

\begin{abstract}
Female agricultural land ownership and operatorship are on the rise in Iowa and across the nation, but little research exists that explores agricultural conservation outreach to women and gendered differences in conservation knowledge and attitudes. The authors surveyed all agricultural landowners and operators in the Clear Creek Watershed in eastern Iowa about conservation knowledge and attitudes, as well as preferred sources of information about conservation. Clear Creek is a high-visibility watershed for conservation outreach for several reasons, including its long-standing watershed stakeholder council and its connection to the impaired Iowa River. Analysis of the survey results demonstrated that female respondents had significantly lower levels of knowledge about best management practices and significantly more positive attitudes towards conservation and collaboration than men. Meanwhile, women looked to the same sources for conservation information as male respondents, including neighbors, friends, and conservation agencies like the Natural Resources Conservation Service, Cooperative Extension, and the Farm Service Agency. These gendered results have significant consequences for the future of agricultural conservation practice and policy and for the subsequent health of the nation's soils and waterways. While lacking in knowledge about specific conservation practices, female respondents valued conservation practices, looked to government agencies for information about conservation, and expressed interest in collaborating with government entities for conservation on their land. Agricultural conservation practitioners can use these findings to tailor outreach efforts that will more effectively reach the nation's female landowners and operators.
\end{abstract}

Key words: conservation — farmer attitudes — female landowners—female operatorsgender-watershed management

The times they are a-changin': female agricultural land ownership and operatorship are on the rise in lowa, and female agricultural landowners and operators may have different conservation outreach needs than their male counterparts. Shifts in land ownership mean that Iowa women now own a majority of the rented farmland in Iowa and own or co-own just under half of Iowa's overall farmland (Duffy and Smith 2008), while single women own a full fifth of Iowa's farmland (Clayton 2009). Female operatorship is on the rise across the state and nationwide (USDA NASS 2009). Meanwhile, throughout the agricultural Midwest, conservation staff and policymakers are under increasing pressure to understand who conserves soil and water and how best to reach them. However, relatively little research exists that works to understand how female agricultural landowners and operators might differ from their male counterparts when it comes to conservation. This is an issue likely to become more and more important as agricultural production in the United States intensifies to meet increasing global demand for food, feed, fiber, and fuel. To help fill this research gap, in 2010 we distributed a survey about conservation knowledge and attitudes and the potential for biofuel production to all agricultural landowners and operators in the Clear Creek Watershed in eastern Iowa. Here we focus on the subset of questions about conservation to consider whether and how female agricultural landowners and operators differ from their male counterparts
- Are there gendered differences between agricultural landowners' and operators' attitudes towards soil and water conservation?

- Are there gendered differences between agricultural landowners' and operators' perceptions of who should be responsible for soil and water conservation in the watershed?

- Are there gendered differences between agricultural landowners' and operators' knowledge of various best management practices and their usefulness in the Clear Creek Watershed?

- Are there gendered differences between agricultural landowners' and operators' weighting of issues that matter to the future of agriculture in Iowa?

- Are there gendered differences between agricultural landowners' and operators' preferred sources of conservation information? Our research questions build upon a thread of Journal of Soil and Water Conservation A Section articles related to the subject of conservation outreach to women (Everett 1983; Carolan et al. 2004; Wells and Eells 2011). A generation ago, Everett (1983) famously claimed that, "Farm girls care about the soil. So do their mothers," and went on to assert that conservation outreach has largely failed to involve women. Twenty years later, Carolan et al. (2004) were still able to describe the "alienation of female landlords" who lacked the technical expertise to deal with their male tenants. Most recently, Wells and Eells (2011) reminded us of Everett's (1983) arguments, suggesting that government conservation programs and staff members are still not working to connect with women landowners, and that this disconnect has a negative impact on conservation throughout Iowa. As they argue, "It is in the best interest of the land to cater more to women farmland owners, as their numbers have grown. We need to step back and rethink programs from their standpoints; evaluate the adequacy

Caroline Gottschalk Druschke is an assistant professor in the Department of Writing and Rhetoric at the University of Rhode Island in Kingston, Rhode Island. Silvia Secchi is an assistant professor in the Department of Agribusiness Economics at Southern Illinois University in Carbondale, Illinois. 
of the one-size, land-as-commodity model; and take an institutional accounting to identify endemic barriers to greater participation" (Wells and Eells 2011). Wells and Eells (2011) argue that conservation agencies have not worked to connect with women landowners, and, as a result, women landowners are not fully participating in decision-making about production practices, commodity programs, and conservation programs on their farmland.

For the reasons that Wells and Eells (2011) describe, women are not participating as often as men in government-sponsored conservation programs. Our research suggests that they are also not as likely to adopt conservation practices more generally. The Census of Agriculture does not provide information on the adoption of conservation by gender, but our study asked about the presence of four conservation practices on the land owned or farmed by respondents, all of which are likely to be supported by cost-share or incentive funding: contour buffer strips, riparian buffers or filter strips, grassed waterways, and terraces or basins. Among female respondents, $18 \%$ reported that at least one of those conservation practices was present for which there had been conservation payments in 2009 , and the same percentage reported the presence of at least one practice for which no payments had been received.Among male respondents, the corresponding percentages were higher at $22 \%$ and $24 \%$. Women's lower levels of adoption of both cost-shared and noncost-shared conservation practices exist despite the wider research that demonstrates that women tend to be particularly conservation-minded (Chiappe and Flora 1998; Feldman and Welsh 1995; Hassanein 1999; Meares 1997; Peter et al. 2000; and Salamon 1992). While it would seem that women's views on conservation would make them want to adopt (or want their renters to adopt) conservation practices on their land, Wells and Eells (2011) tell us that women have not had enough contact with government conservation staff to learn about and, thus, adopt both cost-shared and noncost-shared practices. Because many women do not possess technical expertise (Carolan et al. 2004) and feel they cannot access this expertise as "outsiders" (Carolan et al. 2004), they remain conservation-minded nonadopters.

As a largely underserved population, female agricultural landowners and operators remain largely outside of the scope of conservation adoption literature. This may be due to widely held assumptions about the gendered division of agricultural labor that imagine men in charge of farm fields and women in charge of farm families, even though the reality of farm labor may be much more complicated (Trauger et al. 2010; Brandth 1994; Brandth 2002). In the search for consistent and reliable indicators of adoption, researchers have pointed to factors other than gender, such as education (Rahm and Huffman 1984; Saltiel et al. 1994; Okoye 1998), age (Warriner and Moul 1992; Marra and Ssali 1990; Neill and Lee 2001), farm size (Shortle and Miranowski 1986; Clay et al. 1998; Agbamu 1995), erodible soils (Uri 1997; Soule et al. 2000; Pautsch et al. 2001), land tenure (Neill and Lee 1999; Fuglie 1999; Nowak 1987), and wealth (Somda et al. 2002; Swinton 2000; Smit and Smithers 1992), though these authors came to differing conclusions about the positive, negative, or absent correlation between these factors and adoption. Knowler and Bradshaw (2007), in their widely cited review of global conservation adoption literature, determined that few or none of these variables consistently accounted for adoption across the literature and noted gender as significant in only one study with no further comment. While Prokopy et al. (2008) pointed to a number of factors that positively correlated to conservation adoption in their United States-specific review of conservation adoption literature, they suggested only that these factors serve as good starting points for outreach in the absence of locally specific knowledge and emphasized the importance of local social networks and locally tailored conservation outreach. (Indeed, Eells and Adcock [2012] suggest that local social networks or "peerto-peer learning models" may be especially relevant for female landowners. See also Trauger et al. [2010]) However, Prokopy et al. (2008) cited only one study that showed gender as a significant variable, with male gender positively correlating with adoption. Prokopy et al.'s (2008) conclusion echoed that of Knowler and Bradshaw (2007): both articles insisted on the difficulty of settling on consistent variables and suggested that agricultural conservation efforts should be attentive to local conditions and concerns.

Though solutions need to be place specific, women are going to be central to them, due to increasing rates of female operatorship and landownership as women outlive their male spouses and male siblings to inherit increas- ingly larger farms (Duffy 2011; Eastwood et al. 2010). Women operators are a largely understudied population. The last year that the Iowa Farm and Rural Life Poll (known as the Farm Poll) reported the gender breakdown of respondents was 2008, at which point only $8 \%$ of the survey participants were women (Arbuckle et al. 2008). The second understudied axis of our research is that of landowners. In a recent topical report of the Farm Poll, Arbuckle (2010) noted, "Given the prevalence of rented land in Iowa agriculture, surprisingly little is known about the people who own that land and what impacts nonoperator landownership might have on farmers, rural communities, and the environment." Landowners are an important group to understand because they are involved in one-time decision making about the installation of structural practices and multiyear decisions such as the planting of perennial crops or land set aside. This involvement is likely not on the wane since increases in crop prices in recent years have increased cash rents and decreased the attractiveness of long-term leases (Kauffman 2012), so landowners have more incentives to actively manage their land. Further, there is evidence from the Farm Poll that landowners' connections to farming decisions on their land are still strong - at least in Iowa (Arbuckle 2010). As our study attends to male and female landowners and operators in a watershed in the heart of the Corn Belt, the most productive commodity region in the United States, our results illustrate some of the issues that outreach and extension will have to address in this critical region (figure 1).

\section{Materials and Methods}

Study Site. Our research is based in the Clear Creek Watershed, the 26,300 ha $(65,000 \mathrm{ac})$ watershed in eastern Iowa's Johnson and Iowa counties fed by the $40 \mathrm{~km}(25 \mathrm{mi})$ long Clear Creek (figure 1). Land use in the Clear Creek Watershed in 2009 (figure 2) reflected a more diverse landscape than Iowa as a whole. Twenty-nine percent of the area was planted in corn (Zea mays L.), and $22 \%$ in soybeans (Glycine $\max$ L.), while pasture, grasslands, and alfalfa (Medicago sativa) took up about $27 \%$ of the watershed (over one-sixth of which was enrolled in the Conservation Reserve Program). Urban areas and other impervious surfaces, such as roads, took up about $14 \%$ of the land. By contrast, almost $35 \%$ of land statewide was 
used for growing corn and 22\% for soybeans, while less than $21 \%$ was in pasture, alfalfa, or grasses, and less than 9\% was urban areas and impervious surfaces (USDA NASS 2010). The watershed's more mixed land use reflects its proximity to Iowa City and the fact that the land in the watershed is not as fertile as the land in North-Central Iowa. The higher average slope in the watershed is the reason why, according to Iowa Department of Natural Resources's estimates, most of the watershed does not need to be tiled (Iowa Department of Natural Resources 2008), though anecdotal evidence from J. Schnoor (personal communication, 2010) suggests tiling is present throughout the study area. The main rotations in the watershed are corn-soybean and corn-corn-soybean with a combination of no-till and mulch-tillage. For cow-calf operations in the watershed, the predominant rotation is corn/corn/oats followed by two or three years of meadow. According to J. Martin, (personal communication, February 15, 2012) most of the farmers plow the meadow the year it goes into corn, with some minimum till following row-crop years. According to the most recent data available (Iowa Department of Natural Resources 2012), in 2012 there were four active animal feeding operations, one inactive one, and an open feedlot in the watershed (figure 2). None of the operations was big enough to require a permit. The 2007 Total Maximum Daily Load (TMDL) document reported that the watershed housed 5,945 beef cattle and 8,350 hogs. These numbers were estimated using 2002 county-level census data and are likely not very precise (Iowa Department of Natural Resources 2007). Since the watershed has such a mixed land use and likely has substantial areas that are not tiled, there is a wide range of potentially effective conservation practices including conservation tillage, manure management, riparian buffers, and land set aside.

In the late 1990 s, concerns about pollution in Clear Creek prompted the Johnson County Soil and Water Conservation District to name the creek a priority watershed; the formation of a citizen-based watershed group, the Clear Creek Watershed Enhancement Project (CCWEP), followed in 2000. Clear Creek Watershed Enhancement Project, a group that includes private, business, and governmental stakeholders, as well as conservation staff from the Natural Resources Conservation Service (NRCS),

\section{Figure 1}

Map of the Clear Creek Watershed and its position in the Corn Belt.
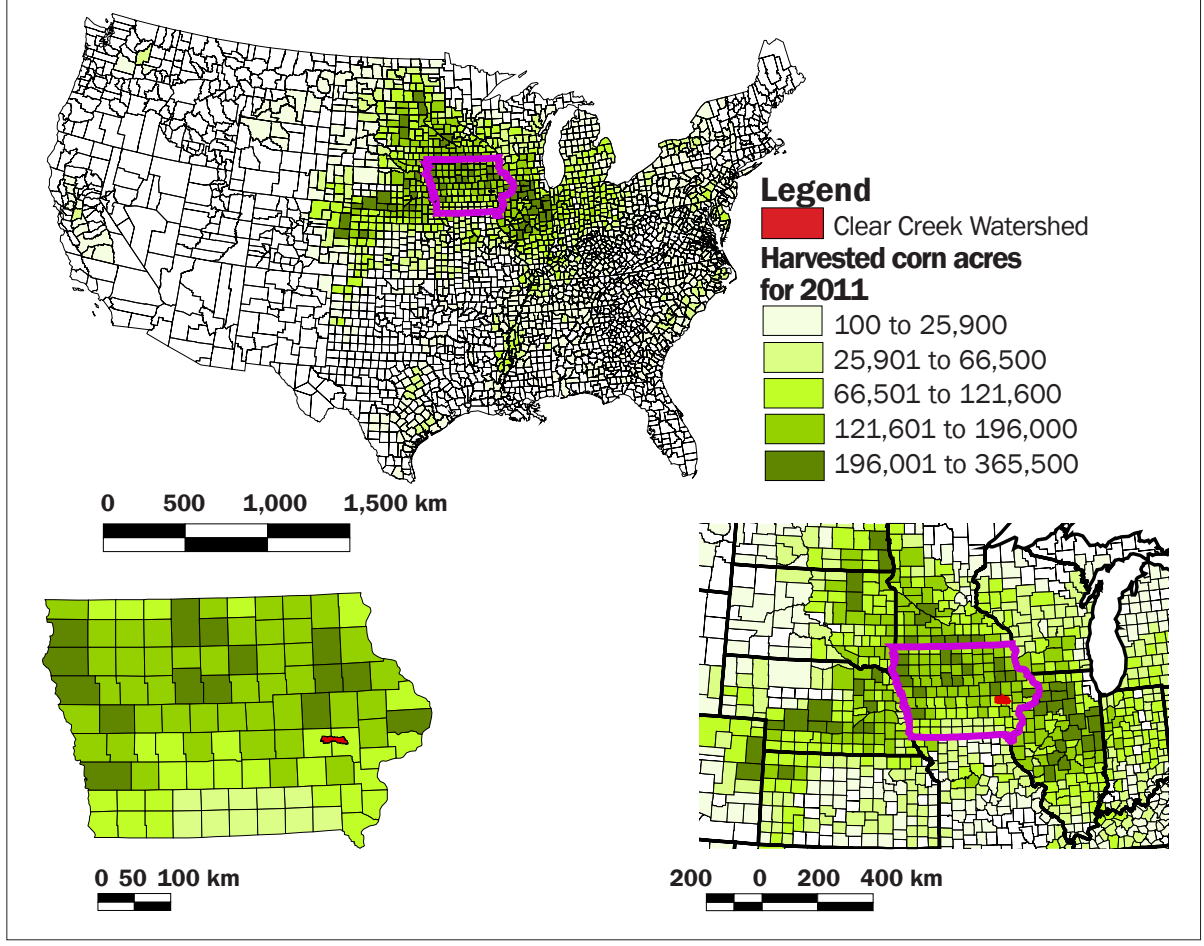

Figure 2

Map of land use in Clear Creek Watershed in 2009.

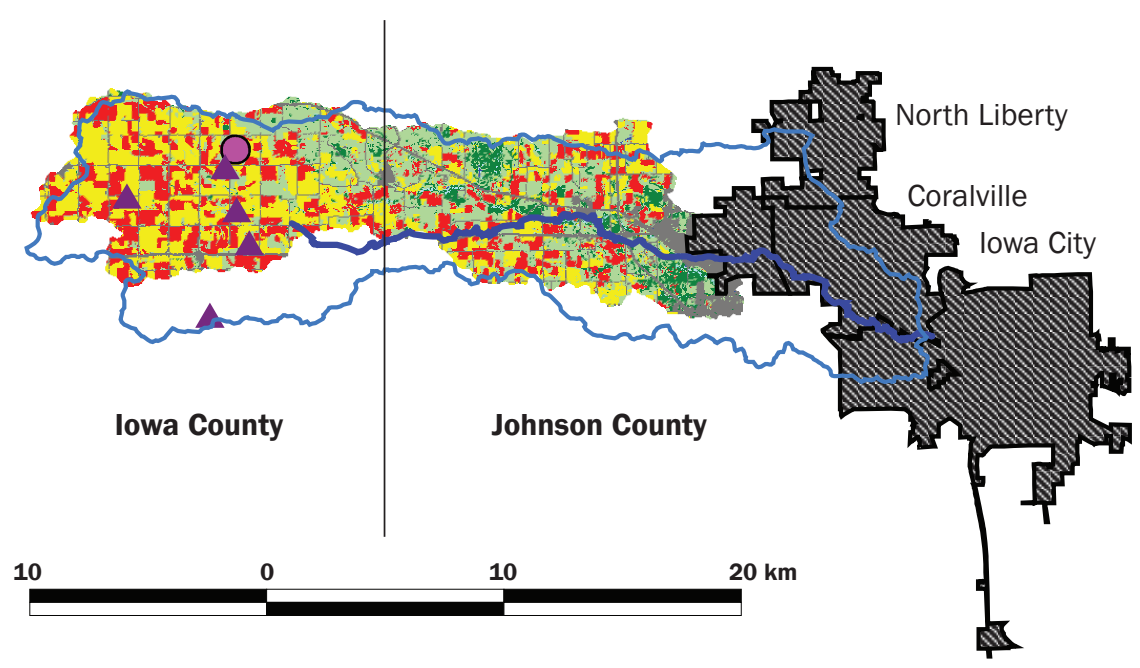

Legend

Clear Creek
Incorporated cities

Livestock

$\Delta$ Confinement

Open feedlot
Land use in 2009

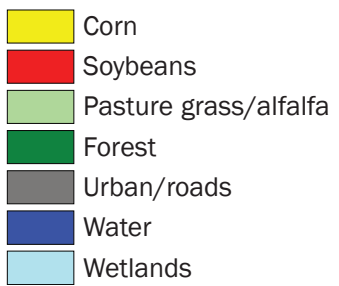


the Iowa Department of Agriculture and Land Stewardship, and the Johnson and Iowa County Soil and Water Conservation Districts, formed to address high bacteria levels, sedimentation, and elevated nitrogen $(\mathrm{N})$ and phosphorous (P) levels in Clear Creek. Since 2000, CCWEP has worked to spread awareness about conservation practices to remedy pollution and secure additional funding for conservation, while a statewide volunteer water monitoring group called IOWATER conducted water quality snapshots along the creek.

In 2004, an IOWATER volunteer tracked the headwaters of Clear Creek and discovered that the small, unsewered, and unincorporated town of Conroy, Iowa was leaching human waste into the drain tiles that fed the headwaters of the creek. This was the starting point for the inclusion of Clear Creek on the United States Environmental Protection Agency's (USEPA) 303(d) Impaired Waters list, which made Clear Creek eligible for US $\$ 1.5$ million in federal grants for remediation efforts (Soenen 2008). The TMDL document produced because of the listing process identified the main sources of pollution as failing septic systems and livestock from direct effects such as cattle in the streams and indirect effects such as inappropriate manure applications (Iowa Department of Natural Resources 2007). As a result, the community of Conroy inaugurated its sewage treatment lagoon in summer 2009, and some farmers in the watershed obtained Clean Water Act 319 funds to install conservation practices such as water and sediment control basins, grade stabilization structures, grassed waterways, filter strips, contour buffers, conservation cover, no-till planting, and fencing for livestock (USEPA 2012). Due to these actions, Clear Creek was removed from the Impaired Waters list in 2010.

Despite the Creek's delisting, pollution remains a problem (Bannow 2013), along with the important reality that the creek flows directly into the Iowa River, a USEPA Impaired Waterway. Despite the early and intense focus on elevated bacteria levels from septics in Clear Creek, the more persistent threat comes from the cumulative impacts of several sources: livestock damage to the creek banks, fecal contamination from manure, runoff from fertilizers and pesticides, and high rates of sheet and rill erosion in the watershed (Bannow 2013; USDA NRCS 2012).
Survey Design and Distribution. Our survey was conducted in 2010 with a dual purpose. The first was to assess the current state of conservation knowledge and attitudes in the watershed to help map out future programs, and the second was to assess potential production scenarios in the watershed, with a particular focus on biofuel production. The first eight questions of the survey were demographic questions about factors like gender, age, income, and education. Question nine (Q.9) asked about knowledge of water quality issues in the watershed. Questions 10 through 13 asked about attitudes towards and knowledge of watershed conservation more generally, while Q.14 asked about preferred sources of information on conservation issues. The remaining survey questions (not analyzed for this study) related to willingness to adopt on-farm conservation practices and knowledge of biofuel production processes. The research presented here is drawn from the subset of questions about conservation knowledge and attitudes.

The survey was conducted by mail. The watershed coordinator compiled the data for the mailing list from the watershed's two counties and from multiple government offices. For Johnson County, landowners from the cities of Coralville, North Liberty, Tiffin, and Oxford were removed from the full county geographic information system (GIS) parcel data in order to exclude urban landowners from the survey. Names on a hard copy list of agricultural landowners and renters from the Johnson County Farm Service Administration (FSA) office were then cross-referenced with the FSA common land unit GIS layer for the watershed. For Iowa County, a list of tract/farm numbers in the watershed was provided to the Iowa County FSA using the common land unit GIS layer. Based on that list of tract/farm numbers, the Iowa County FSA office provided a hard copy list of the associated owners and operators for each tract/ farm. Hard copies were then typed into a Microsoft Excel spreadsheet, which was used to create mailing labels.

In April of 2010, the survey was mailed to all 998 nonurban landowners and agricultural operators in the Clear Creek Watershed. Two reminder mailings were sent out over the coming weeks, and, finally, a second survey was mailed to nonresponders. Budgetary restrictions limited any additional mailings. Respondents received a US $\$ 30$ check as compensation for their time and were entered into a raffle drawing for two US $\$ 20$ value trees and one US $\$ 50$ plant sale gift certificate. Thirty-one of the surveys were returned as undeliverable. Of the 967 surveys that were delivered, 397 were at least partially completed for a response rate of $41.1 \%$. Three hundred ninety-two (representing 225 males and 167 females) of those 397 surveys (40.5\% of the delivered surveys) contained enough demographic information to analyze. The project was approved by the Institutional Review Boards at the investigators' universities. Characteristics of the entire population being sampled were not available; therefore testing for nonresponse bias was not possible. However, the characteristics of our respondents are consistent with those of the statewide population included in the statewide Farmland Ownership and Tenure (FOT) survey that Iowa State University conducts every five years. Forty-two percent of survey respondents were women, and the average age was 62 years for the men and 59 years for the women. In the last available FOT report, women owned $47 \%$ of land statewide. Age-wise, direct comparisons are not possible, since the FOT does not report averages, but in $2007,61 \%$ of the land owned by women was owned by those over 65 years, and $51 \%$ of the land owned by men was owned by men over 65 years. Overall, $55 \%$ of Iowa farmland was owned by people over the age of 65 (Duffy and Smith 2008).

Survey Analysis. We analyzed questions related to respondents' views about conservation, knowledge about best management practices, collaboration for watershed-based conservation, issues that matter most to the future of agriculture in Iowa, and sources of information about conservation (table 1). Using SPSS software, we calculated Independent Samples $t$-tests and Spearman rank correlation coefficients for the Likertbased questions (Clason and Dormody 1994). Preliminary F-tests for the equality of variances were conducted to determine whether to perform $t$-tests assuming equal or different variances.

The survey opened with 8 demographic questions. Question 9 asked respondents how knowledgeable they were about the water quality issues facing the Clear Creek Watershed. Broad knowledge and attitudes about conservation and responsibilities for its implementation were the focus of 10 subquestions in Q.10, set up as a five-point 
Likert scale where respondents were asked to indicate their level of agreement or disagreement with a series of statements. The issues of collaboration and responsibility for the implementation of conservation practices were also at the core of Q.11, which asked respondents to indicate who should be responsible for soil and water conservation in the watershed. Knowledge about specific conservation practices and activities was the focus of Q.12, which asked respondents to indicate how effective the respondents felt specific practices would be in improving water quality in the watershed. Outlook towards the future was the focus of 8 subquestions in Q.13, which asked respondents how important they thought a variety of issues were for the future of Iowa's agriculture using a five-point Likert scale. Sources of conservation information were the focus of Q.14.

\section{Results and Discussion}

Female and male respondents had statistically significant differing responses for a variety of questions related to broad conservation knowledge and attitudes, collaboration for conservation, knowledge of specific conservation practices, and outlook towards the future of agriculture. They had similar responses to questions about local water quality issues and sources of conservation information.

Women and Men Both Reported a Similar Lack of Knowledge about Water Quality Issues in the Clear Creek Watershed (Table 2). Question 9 asked respondents, "On a scale of 1 to 5 how knowledgeable are you about the water quality issues facing the Clear Creek Watershed?" where one indicated "not at all knowledgeable" and five indicated "very knowledgeable." We hypothesized that male respondents would have more knowledge about local water quality issues than female respondents, but this was not the case. Both men and women indicated that they were closer to "not at all knowledgeable" than "very knowledgeable" on a five-point scale $($ men $=2.30$, women $=2.24$, $p=0.429$ ), with no statistically significant difference between the two groups.

Women Reported Knowing Less about Conservation Than Their Male Counterparts and Were Less Likely to Think of Themselves as Agricultural Stewards (Table 2). Question 10 used a Likert scale $(1=$ strongly disagree, $2=$ disagree, $3=$ neutral, $4=$ agree, and $5=$ strongly agree) to ask respondents to indi- cate their level of agreement or disagreement with several statements. The first was (Q.10a) "I know what steps to take to conserve soil and water on my land." Because we thought that men would have more concrete knowledge about conservation practices than women and would be more confident about their conservation knowledge, we hypothesized that women would report a statistically significant lower mean than men, and this was the case (women $=3.68$, men $=3.93, p$ $=0.002)$. Question 10i asked respondents to indicate their level of agreement or disagreement with the statement, "I consider myself a steward of the land." Because we thought that women would be less confident about their conservation knowledge and see themselves as less empowered, we hypothesized that women would report a statistically significant lower mean than men, and this was the case at $10 \%$ significance (women $=4.01$, men $=4.14, p=0.076)$.

Women Reported Being More Concerned about Soil and Water Conservation Than Their Male Counterparts (Table 2). Question $10 \mathrm{c}$ asked respondents to indicate their level of agreement or disagreement with the statement, "I think soil and water conservation are important," while Q.10e asked respondents to consider the statement, "I think water contamination (from fertilizers, sediments, and septics) is an important environmental problem in our watershed." Because we thought that women would be more conservation-minded than their male counterparts, we hypothesized that women would report statistically significant higher means than men, and this was the case at $10 \%$ significance for both subquestions (Q.10c women $=4.49$, men $=4.38, p=0.097 ; \mathrm{Q} .10 \mathrm{e}$ women $=3.80$, men $=3.63, p=0.069)$.

Women Were More Likely to Value Collaboration for Conservation (Table 2). While there was not a statistically significant difference between female and male respondents for the statement in Q.10g, "I think farmers and other watershed residents should work together to protect our watershed," both respondent groups more than agreed with this statement (women = 4.19 , men $=4.09, p=0.132$ ). Question $10 \mathrm{~h}$ asked respondents to indicate their level of agreement or disagreement with the statement, "I think farmers and conservation agency staff should work together to protect our watershed." We hypothesized that women would report a statistically significant higher mean than men, and this was the case at $10 \%$ significance (women = 4.17 , men $=4.00, p=0.053)$.

Women Were More Likely Than Men to Encourage Public-Private Collaboration for Conservation (Table 2). Question 11 asked, "Who should be responsible for soil and water conservation? (Check all that apply.)" Possible answers were landowners, government conservation staff, farm managers, Clear Creek Watershed Board, renters, and specified others. In Q.11, many respondents indicated that private actors including landowners, farm managers, and renters (or a subset of these) should be responsible for conservation, while other respondents indicated that a subset of or all private actors should be responsible along with a subset of or all public actors (government conservation staff and the Clear Creek Watershed Board). Based on these themes, we created a "private only" variable and a "public-private" variable, groupings that successfully captured $96 \%$ of female respondents and $96 \%$ of male respondents. We hypothesized that women would be more likely than men to encourage public-private collaboration, and this was the case. When we analyzed the responses for the "private only" variable, we found a statistically significant difference $(p=0.003)$ between women and men. Twenty-seven percent of women and $41 \%$ of men indicated that private parties (without the assistance of public entities) should be solely responsible for soil and water conservation in the watershed. When we analyzed the responses for the "public-private" variable, we again found a statistically significant difference $(p=0.006)$ between women and men. Sixty-nine percent of women and $56 \%$ of men responded that private and public parties should both be responsible for soil and water conservation in the watershed.

Women Thought Specific Conservation Practices Were Less Effective Than Men Did (Table 2). Question 12 asked respondents about the effectiveness of specific practices in improving water quality in the watershed. The question was set up as a three-point Likert scale $(1=$ not at all effective, $2=$ somewhat effective, and 3 = very effective). Respondents were given the additional option $0=$ unsure. Because we anticipated that respondents might offer a low rating of a specific conservation practice based on the needs of their particular land holdings or farming operations, we asked respondents about each practice's effectiveness for 
Table 1

Survey questions analyzed for this study of landowner and operator conservation attitudes and behaviors in the Clear Creek Watershed, distributed in 2010 as a mailed survey to all agricultural landowners and operators in the watershed.

\begin{tabular}{|c|c|c|}
\hline ID & \multicolumn{2}{|c|}{ Question } \\
\hline Q.2 & \multicolumn{2}{|c|}{ Are you male or female? } \\
\hline Q.9 & \multicolumn{2}{|r|}{ On a scale of 1 to 5 how knowledgeable are you about the water quality issues facing the Clear Creek Watershed? } \\
\hline \multirow[t]{11}{*}{ Q.10 } & \multicolumn{2}{|r|}{ Please indicate your level of agreement or disagreement with the following statements. } \\
\hline & Q.10a & I know what steps to take to conserve soil and water on my land. \\
\hline & Q.10b & I think farmers take undue blame for environmental problems in the watershed. \\
\hline & Q.10c & I think soil and water conservation are important. \\
\hline & Q.10d & $\begin{array}{l}\text { I think farming practices and land use (planting grass along streams) should be regulated to reduce pollution to } \\
\text { surface water. }\end{array}$ \\
\hline & Q.10e & I think water contamination (from fertilizers, sediments, and septics) is an important environmental problem in our watershed. \\
\hline & Q.10f & I think commodity payments impact my decisions about soil and water conservation. \\
\hline & Q.10g & I think farmers and other watershed residents should work together to protect our watershed. \\
\hline & Q.10h & I think farmers and conservation agency staff should work together to protect our watershed. \\
\hline & Q.10i & I consider myself a steward of the land. \\
\hline & Q.10j & I think about the effects that my management choices have on the rest of the watershed. \\
\hline Q.11 & \multicolumn{2}{|r|}{ Who should be responsible for soil and water conservation? (Check all that apply.) } \\
\hline \multirow[t]{8}{*}{ Q.12 } & \multicolumn{2}{|r|}{ How effective do you feel the following management practices would be in improving water quality in your watershed? } \\
\hline & Q.12a & Plant temporary winter cover (such as oats or rye) between rotations of corn and beans \\
\hline & Q.12b & Better nutrient management \\
\hline & Q.12c & Marketing of alternative crops (such as hay, organic, switchgrass, and cattle) \\
\hline & Q.12d & Better record keeping systems \\
\hline & Q.12e & Better tillage system management \\
\hline & Q.12f & Better erosion control management (such as terraces or contour buffer strips) \\
\hline & Q.12g & Application of manure based on nutrient content and soil test results \\
\hline \multirow[t]{9}{*}{ Q.13 } & \multicolumn{2}{|c|}{ How important do you think the following issues are for the future of lowa's agriculture? } \\
\hline & Q.13a & Aging of farmers \\
\hline & Q.13b & Bioenergy production (such as ethanol from corn) \\
\hline & Q.13c & Environmental impact of farming (for example on water quality) \\
\hline & Q.13d & Federal legislation (such as the Farm Bill) \\
\hline & Q.13e & International trade and trade agreements \\
\hline & Q.13f & Land values \\
\hline & Q.13g & Production costs (such as fuel, pesticides, and feed) \\
\hline & Q.13h & Wildlife habitat and recreation (such as hunting) \\
\hline
\end{tabular}

“improving water quality in your watershed," rather than on their specific parcels. Each of the practices listed would be effective in improving water quality in the Clear Creek Watershed. Specifically, since about half the total area of the watershed is used for corn and soybean production, and the watershed is not flat, we asked about cover crops, which have a host of benefits, including reducing erosion. Given the high level of homogeneity of crops grown, we also asked about the marketing of alternative crops such as switchgrass
(Panicum virgatum) and livestock because they would increase the diversity of land uses in the watershed and require fewer artificial fertilizers and pesticides. We also asked about record keeping because the current (just expired) Farm Bill includes provisions in the Environmental Quality Incentives Program (EQIP) for nutrient management plans. Environmental Quality Incentives Program, by far the largest working land conservation program in the United States (Osteen et al. 2012), provides incentives for such plans, and there is evidence that - at least in the case of hog production - it is the most common conservation practice adopted in the industry (Key et al. 2011). We hypothesized that women would rank each conservation practice as less effective than men would due to lack of knowledge. This proved to be the case for four of the seven subquestions and is illustrated further by the fact that women are more unsure of conservation, as discussed in more detail below. 
Table 2

Sample sizes, means, Spearman test results, and $t$-test results for survey questions analyzed for the 2010 study of landowner and operator conservation attitudes and behaviors in the Clear Creek Watershed.

\begin{tabular}{|c|c|c|c|c|c|c|c|c|}
\hline ID & \multicolumn{2}{|c|}{ Question } & $\begin{array}{l}\text { Men } \\
\text { mean } \\
\text { response }\end{array}$ & $\begin{array}{l}\text { Men } \\
\text { group } \\
\text { size }\end{array}$ & $\begin{array}{l}\text { Women } \\
\text { mean } \\
\text { response }\end{array}$ & $\begin{array}{l}\text { Women } \\
\text { group } \\
\text { size }\end{array}$ & $\begin{array}{l}\text { Spearman's } \\
\text { rho }\end{array}$ & p \\
\hline \multirow[t]{2}{*}{ Q.9 } & \multicolumn{2}{|c|}{$\begin{array}{l}\text { On a scale of } 1 \text { to } 5 \text { how knowledgeable are you about the } \\
\text { water quality issues facing the Clear Creek Watershed? } \\
\text { Answer choices: not at all knowledgeable (1) to very }\end{array}$} & 2.30 & 219 & 2.24 & 164 & 0.038 & 0.429 \\
\hline & \multicolumn{2}{|c|}{ knowledgeable (5). } & & & & & & \\
\hline \multirow[t]{11}{*}{ Q.10 } & \multicolumn{2}{|c|}{$\begin{array}{l}\text { Please indicate your level of agreement or disagreement } \\
\text { with the following statements from the choices: strongly } \\
\text { disagree (1), disagree (2), neutral (3), agree (4), } \\
\text { and strongly agree (5). }\end{array}$} & & & & & & \\
\hline & Q.10a & $\begin{array}{l}\text { I know what steps to take to conserve soil and } \\
\text { water on my land. }\end{array}$ & 3.93 & 222 & 3.68 & 163 & 0.155 & $0.002 * * *$ \\
\hline & Q.10b & $\begin{array}{l}\text { I think farmers take undue blame for } \\
\text { environmental problems in the watershed. }\end{array}$ & 3.56 & 220 & 3.53 & 161 & 0.018 & 0.731 \\
\hline & Q.10c & I think soil and water conservation are important. & 4.38 & 215 & 4.49 & 159 & -0.086 & $0.097 *$ \\
\hline & Q.10d & $\begin{array}{l}\text { I think farming practices and land use (planting } \\
\text { grass along streams) should be regulated to } \\
\text { reduce pollution to surface water. }\end{array}$ & 3.31 & 222 & 3.48 & 162 & -0.063 & 0.217 \\
\hline & Q.10e & $\begin{array}{l}\text { I think water contamination (from fertilizers, } \\
\text { sediments, and septics) is an important } \\
\text { environmental problem in our watershed. }\end{array}$ & 3.63 & 222 & 3.80 & 164 & -0.093 & $0.069 *$ \\
\hline & Q.10f & $\begin{array}{l}\text { I think commodity payments impact my } \\
\text { decisions about soil and water conservation. }\end{array}$ & 3.01 & 217 & 3.06 & 161 & -0.018 & 0.727 \\
\hline & Q.10g & $\begin{array}{l}\text { I think farmers and other watershed residents } \\
\text { should work together to protect our watershed. }\end{array}$ & 4.09 & 222 & 4.19 & 163 & -0.077 & 0.132 \\
\hline & Q.10h & $\begin{array}{l}\text { I think farmers and conservation agency staff } \\
\text { should work together to protect our watershed. }\end{array}$ & 4.00 & 222 & 4.17 & 163 & -0.099 & $0.053 *$ \\
\hline & Q.10i & I consider myself a steward of the land. & 4.14 & 219 & 4.01 & 158 & 0.092 & $0.076 *$ \\
\hline & Q.10j & $\begin{array}{l}\text { I think about the effects that my management } \\
\text { choices have on the rest of the watershed. }\end{array}$ & 3.95 & 218 & 3.86 & 162 & 0.068 & 0.186 \\
\hline \multirow[t]{3}{*}{ Q.11 } & \multicolumn{2}{|c|}{$\begin{array}{l}\text { Who should be responsible for soil and water conservation } \\
\text { in the watershed? (Check all that apply.) Answer } \\
\text { choices: land owners, farmers, renters (grouped as } \\
\text { private), government conservation staff, and } \\
\text { Clear Creek Watershed Board (grouped as public), } \\
\text { and specified other. }\end{array}$} & $\begin{array}{l}\text { Men } \\
\text { mean } \\
\text { response }\end{array}$ & $\begin{array}{l}\text { Men } \\
\text { group } \\
\text { size }\end{array}$ & $\begin{array}{l}\text { Women } \\
\text { mean } \\
\text { response }\end{array}$ & $\begin{array}{l}\text { Women } \\
\text { group } \\
\text { size }\end{array}$ & $t$ statistics & $p$ \\
\hline & Q.11a & Private only & 0.41 & 213 & 0.27 & 157 & -2.970 & $0.003 * * *$ \\
\hline & Q.11b & Public and private & 0.56 & 213 & 0.69 & 157 & 2.788 & $0.006 * * *$ \\
\hline \multirow[t]{8}{*}{ Q.12 } & \multicolumn{2}{|c|}{$\begin{array}{l}\text { How effective do you feel the following management } \\
\text { practices would be in improving water quality in your } \\
\text { watershed? Answer choices: not at all effective } \\
\text { (1), somewhat effective (2), very effective } \\
\text { (3), and unsure (0). }\end{array}$} & $\begin{array}{l}\text { Men } \\
\text { mean } \\
\text { response }\end{array}$ & $\begin{array}{l}\text { Men } \\
\text { group } \\
\text { size }\end{array}$ & $\begin{array}{l}\text { Women } \\
\text { mean } \\
\text { response }\end{array}$ & $\begin{array}{l}\text { Women } \\
\text { group } \\
\text { size }\end{array}$ & $\begin{array}{l}\text { Spearman's } \\
\text { rho }\end{array}$ & p \\
\hline & Q.12a & $\begin{array}{l}\text { Plant temporary winter cover (such as oats or rye) } \\
\text { between rotations of corn and beans }\end{array}$ & 1.53 & 219 & 1.27 & 161 & 0.106 & $0.039 * *$ \\
\hline & Q.12b & Better nutrient management & 1.74 & 218 & 1.47 & 159 & 0.104 & $0.044 * *$ \\
\hline & Q.12c & $\begin{array}{l}\text { Marketing of alternative crops (such as hay, } \\
\text { organic, switchgrass, and cattle) }\end{array}$ & 2.00 & 217 & 1.60 & 159 & 0.162 & $0.002 * * *$ \\
\hline & Q.12d & Better record keeping systems & 1.47 & 219 & 1.32 & 154 & 0.064 & 0.215 \\
\hline & Q.12e & Better tillage system management & 2.36 & 214 & 2.04 & 157 & 0.124 & $0.017 * *$ \\
\hline & Q.12f & $\begin{array}{l}\text { Better erosion control management (such as } \\
\text { terraces or contour buffer strips) }\end{array}$ & 2.40 & 220 & 2.24 & 160 & 0.024 & 0.635 \\
\hline & Q.12g & $\begin{array}{l}\text { Application of manure based on nutrient } \\
\text { content and soil test results }\end{array}$ & 1.72 & 219 & 1.55 & 158 & 0.027 & 0.607 \\
\hline
\end{tabular}

Notes: $n=397$. Response rate $41.1 \%$.

$* p<0.10 * * p<0.05 * * * p<0.01$ 


\section{Table 2 continued}

Sample sizes, means, Spearman test results, and $t$-test results for survey questions analyzed for the 2010 study of landowner and operator conservation attitudes and behaviors in the Clear Creek Watershed.

\begin{tabular}{|c|c|c|c|c|c|c|c|c|}
\hline \multirow[t]{9}{*}{ Q.13 } & \multicolumn{2}{|c|}{$\begin{array}{l}\text { How important do you think the following issues are for } \\
\text { the future of lowa's agriculture? Answer choices: } \\
\text { not important at all (1), somewhat unimportant (2), neutral } \\
\text { (3), somewhat important (4), and very important (5). }\end{array}$} & \multirow{2}{*}{$\begin{array}{l}\text { Men } \\
\text { mean } \\
\text { response } \\
3.81\end{array}$} & \multirow{2}{*}{$\begin{array}{l}\text { Men } \\
\text { group } \\
\text { size } \\
219\end{array}$} & \multirow{2}{*}{$\begin{array}{l}\text { Women } \\
\text { mean } \\
\text { response } \\
4.11\end{array}$} & \multirow{2}{*}{$\begin{array}{l}\text { Women } \\
\text { group } \\
\text { size } \\
159\end{array}$} & \multirow{2}{*}{$\begin{array}{l}\text { Spearman's } \\
\text { rho } \\
-0.156\end{array}$} & \multirow{2}{*}{$\begin{array}{l}p \\
0.002 * * *\end{array}$} \\
\hline & Q.13a & Aging of farmers & & & & & & \\
\hline & Q.13b & Bioenergy production (such as ethanol from corn) & 4.06 & 216 & 4.20 & 154 & -0.094 & $0.072 *$ \\
\hline & Q.13c & $\begin{array}{l}\text { Environmental impact of farming (for example on } \\
\text { water quality) }\end{array}$ & 3.96 & 219 & 4.17 & 158 & -0.117 & $0.023 * *$ \\
\hline & Q.13d & Federal legislation (such as the Farm Bill) & 3.67 & 220 & 3.94 & 158 & -0.150 & $0.003 * * *$ \\
\hline & Q.13e & International trade and trade agreements & 4.09 & 221 & 4.23 & 159 & -0.066 & 0.200 \\
\hline & Q.13f & Land values & 4.13 & 219 & 4.32 & 158 & -0.123 & $0.017 * *$ \\
\hline & Q.13g & $\begin{array}{l}\text { Production costs (such as fuel, pesticides, } \\
\text { and feed) }\end{array}$ & 4.50 & 221 & 4.59 & 160 & -0.083 & 0.107 \\
\hline & Q.13h & Wildlife habitat and recreation (such as hunting) & 3.52 & 217 & 3.67 & 163 & -0.054 & 0.295 \\
\hline \multirow[t]{9}{*}{ Q.14 } & \multicolumn{2}{|c|}{$\begin{array}{l}\text { Who is/are your main source(s) of information on } \\
\text { conservation issues? (Check all that apply.) Answer } \\
\text { choices: Natural Resources Conservation Service, soil } \\
\text { conservation district commissioners, Farm Service } \\
\text { Agency, vocational agriculture instructors, county } \\
\text { extension service (extension), machinery dealers, } \\
\text { lowa State University specialists, private } \\
\text { consultants, local seed/chemical/fertilizer dealers, } \\
\text { nonprofit organizations (e.g., the Nature Conservancy), } \\
\text { neighbors and friends, and specified other. }\end{array}$} & $\begin{array}{l}\text { Men } \\
\text { mean } \\
\text { response }\end{array}$ & $\begin{array}{l}\text { Men } \\
\text { group } \\
\text { size }\end{array}$ & $\begin{array}{l}\text { Women } \\
\text { mean } \\
\text { response }\end{array}$ & $\begin{array}{l}\text { Women } \\
\text { group } \\
\text { size }\end{array}$ & $t$ statistics & $p$ \\
\hline & Q.14a & Nongovernmental organizations & 0.07 & 225 & 0.10 & 167 & 0.882 & 0.378 \\
\hline & Q.14b & Natural Resource Conservation Service & 0.42 & 225 & 0.43 & 167 & 0.176 & 0.860 \\
\hline & Q.14c & Soil conservation district commissioners & 0.20 & 225 & 0.21 & 167 & 0.124 & 0.901 \\
\hline & Q.14d & Farm Service Administration & 0.37 & 225 & 0.35 & 167 & -0.407 & 0.685 \\
\hline & Q.14e & Neighbors and friends & 0.45 & 225 & 0.48 & 167 & 0.591 & 0.555 \\
\hline & Q.14f & County extension & 0.45 & 225 & 0.41 & 167 & -0.823 & 0.411 \\
\hline & Q.14g & lowa State University & 0.23 & 225 & 0.25 & 167 & 0.466 & 0.641 \\
\hline & Q.14h & Seed, chemical, and fertilizer dealers & 0.24 & 225 & 0.20 & 167 & -0.896 & 0.371 \\
\hline
\end{tabular}

Notes: $n=397$. Response rate $41.1 \%$.

$* p<0.10 * * p<0.05 * * * p<0.01$

Women reported a statistically significant lower effectiveness for (Q.12a) "Plant[ing] temporary winter cover (such as oats or rye) between rotations of corn and beans" (women $=1.27$, men $=1.53, p=0.039$ ), (Q.12b) "Better nutrient management" (women $=1.47$, men $=1.74, p=0.044$ ), (Q.12c) "Marketing of alternative crops (such as hay, organic, switchgrass, cattle)" (women = 1.60 , men $=2.00, p=0.002)$, and (Q.12e) "Better tillage management system" (women $=2.04$, men $=2.36, p=0.017)$. There was no significant difference between female and male respondents about the perceived effectiveness of (Q.12d) "Better record keeping systems," (Q.12f) "Better erosion control management (such as terraces or contour buffer strips)," or (Q.12g) "Application of manure based on nutrient content and soil results."

Women Were More Uncertain Than Men of the Effectiveness of Specific Conservation
Practices (Table 3). For Q.12, we hypothesized that women would be more likely to answer "unsure" about the effectiveness of each practice than male respondents, and this was the case for all seven subquestions. As reported in table 3, these were statistically significant differences at the $5 \%$ confidence level in five cases. Women were particularly unsure about marketing and manure issues, illustrating how the knowledge gap spans from on-farm practices and activities to selling and economic issues.

We acknowledge that perceptions of effectiveness could be impacted by factors other than conservation knowledge. One possibility could be that there are differences in the effectiveness of the practices on the land that women own as compared to the land that men own-for example, if men disproportionately owned very unproductive land, they might have more conservation practices on their land and thus be more informed about how well the practices work. This would only hold if there are differences in the types of land that men and women own. The data needed to verify this is not available to us, but there is no apparent reason why that would be the case. Another explanation might be that women are less inclined to follow the advice of conservation professionals. However, as we detailed above, women are more willing than men to work with public sector professionals to address conservation issues.

Women and Men Differently Prioritized Significant Factors for the Future of Iowa Agriculture (Table 2). In Q.13, respondents were asked to rate conservation issues using a five-point Likert scale $(1=$ not important at all, $2=$ somewhat unimportant, $3=$ neutral, $4=$ somewhat important, and $5=$ very important). We hypothesized that female respondents would be more likely than male 
Table 3

Percentage of female and male respondents indicating that they are "unsure" about the effectiveness of specific conservation practices and the associated $p$-values for the $t$-test results in Q.12 from the 2010 study of landowner and operator conservation attitudes and behaviors in the Clear Creek Watershed.

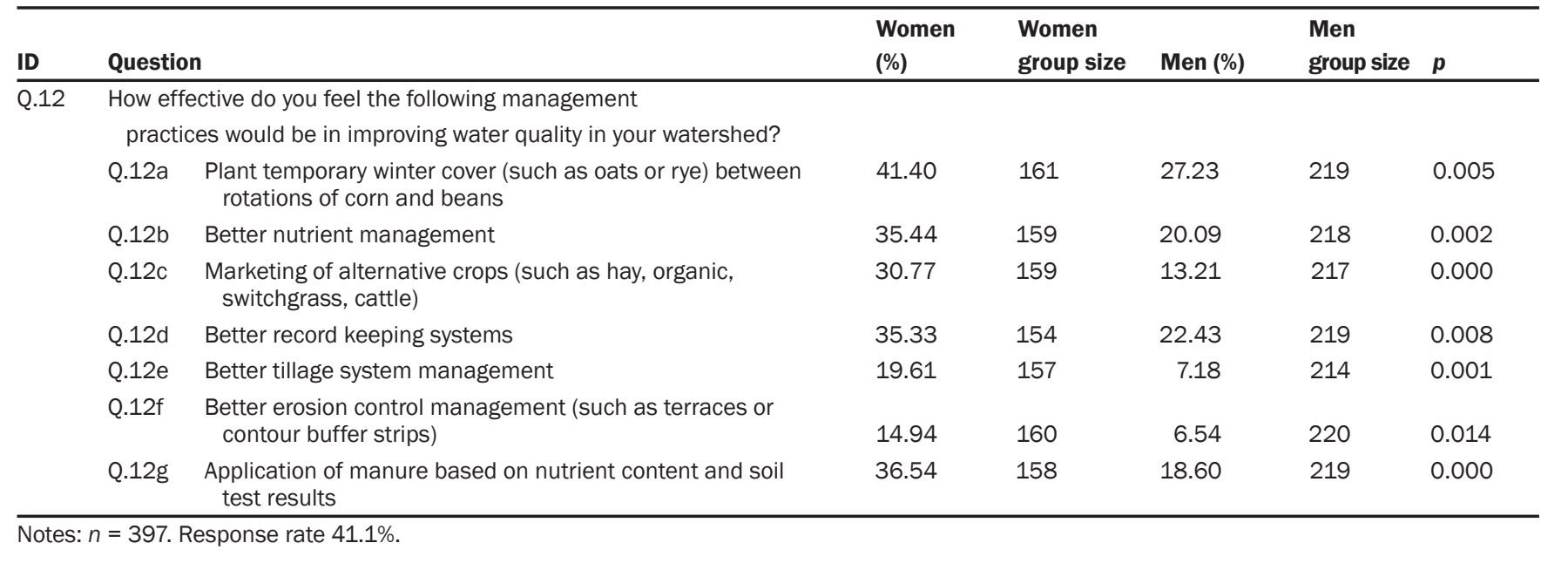

respondents to prioritize conservation issues because the literature shows that women tend to be more conservation-minded than men. We also hypothesized that women would prioritize aging of farmers and land values because as male landowners age and die they frequently leave their estates to female wives, sisters, and daughters. This is especially true for nonfarming landowners. We were partially correct. Female respondents reported higher means than male respondents for all subquestions in Q.13, and these differences were statistically significant for four of the eight subquestions at $5 \%$ significance, including (Q.13a) "Aging of farmers" (women $=4.11$, men $=3.81, p=0.002),(\mathrm{Q} .13 \mathrm{c})$ "Environmental impact of farming (for example on water quality)" (women $=4.17$, men $=3.96, p=0.023)$, (Q.13d) "Federal legislation (such as the Farm Bill)" (women $=3.94$, men $=3.67, p=0.003)$, and (Q.13f) "Land values" $($ women $=4.32$, men $=4.13, p$ $=0.017)$, and one additional question at $10 \%$ significance, (Q.13b) "Bioenergy production (such as ethanol from corn)" (women $=4.20$, men $=4.06, p=0.072$ ).

Female and Male Respondents Looked to Similar Sources to Obtain Information about Conservation Issues (Tables 2 and 4). Question 14 asked, "Who is/are your main source(s) of information on conservation issues? (Check all that apply.)" The possible answers were NRCS, soil conservation district commissioners, Farm Service Agency, vocational agriculture instructors, county extension service, machinery dealers, Iowa State University specialists, private consultants, local seed/chemical/fer- tilizer dealers, nonprofit organizations (e.g., the Nature Conservancy), neighbors and friends, and specified other (e.g., Agricultural Stabilization and Conservation Service). We tallied up the total number of respondents for each possible answer in Q.14 and then compared these responses against one another. We hypothesized that women would have a statistically significant different response than men, indicating that they relied more heavily on sources of information that men relied less heavily on and vice versa. This was not the case. Instead, women and men answered similarly, ranking neighbors and friends (women $=48 \%$, men $=45 \%), \operatorname{NRCS}($ women $=43 \%$, men $=42 \%$ ), county extension (women $=$ $41 \%$, men $=45 \%$ ), and FSA (women $=35 \%$, men $=38 \%)$ as their main sources of information on conservation issues (table 4). There were no statistically significant differences between male and female respondent groups for each possible answer choice (table 4).

\section{Summary and Conclusions}

Even though our results from the Clear Creek Watershed survey largely confirmed our hypotheses, we were surprised by their clarity. We learned that the female landowners and operators responding to our survey differ significantly from male respondents. Female respondents are less knowledgeable about conservation practices, both underestimating (Q.12a, Q.12b, Q.12c, and Q.12e) and being more uncertain about (Q.10a, Q.12a, Q.12b, Q.12c, Q.12d, Q.12e, Q.12f, and $\mathrm{Q} .12 \mathrm{~g}$ ) their efficacy; are more likely to be concerned about soil and water conservation (Q.10c and Q.10e); are more conservation-minded (Q.10c and Q.10e); and see aging, bioenergy production, environmental impacts, federal legislation, and land values as more important to the future of Iowa's agriculture (Q.13a, Q.13b, Q.13c, Q.13d, and Q.13f) than male respondents. These women place responsibility for conservation in both private and public hands more often than male respondents (Q.10h and Q.11), but both genders are interested in collaborating for watershed-based conservation (Q.10g). Both female and male respondents are lacking in knowledge about water quality issues in the study watershed (Q.9) and look to neighbors and friends, NRCS, County Extension Service, and FSA most often for information about conservation issues (Q.14). In short, the female landowners and operators responding to our survey had significantly lower levels of knowledge about best management practices and significantly more favorable attitudes towards conservation and collaboration than their male counterparts, though women relied on the same information sources as men. These findings suggest that traditional conservation institutions are failing to reach female landowners and operators, a conclusion with significant consequences for the future of agricultural conservation practice and the success of the conservation effort in the Clear Creek Watershed, the Corn Belt, and the nation as a whole.

Female operators and landowners will be increasingly important constituencies for conservation outreach and policy in Iowa and throughout the nation as women own and operate growing acres of farmland. Since 
Table 4

Ranked responses to Q.14, "Who is/are your main source(s) of information on conservation issues? (Check all that apply.)" from the 2010 study of landowner and operator conservation attitudes and behaviors in the Clear Creek Watershed.

\begin{tabular}{lccccc}
\hline Source & All respondents & Women & Men & t statistics & $\boldsymbol{p}$ \\
\hline$n$ & 392 & 167 & 225 & & \\
Neighbors and friends & $47 \%$ & $47.90 \%$ & $44.89 \%$ & 0.591 & 0.555 \\
Natural Resource Conservation Service & $43 \%$ & $43.11 \%$ & $42.22 \%$ & 0.176 & 0.860 \\
County extension & $43 \%$ & $40.72 \%$ & $44.89 \%$ & -0.823 & 0.411 \\
Farm Service Administration & $37 \%$ & $35.33 \%$ & $37.33 \%$ & -0.407 & 0.685 \\
lowa State University & $24 \%$ & $25.15 \%$ & $23.11 \%$ & 0.466 & 0.641 \\
Seed, chemical, and fertilizer dealers & $22 \%$ & $19.76 \%$ & $23.56 \%$ & -0.896 & 0.371 \\
Soil conservation district commissioners & $21 \%$ & $20.96 \%$ & $20.44 \%$ & 0.124 & 0.901 \\
Nongovernmental organizations & $8 \%$ & $9.58 \%$ & $7.11 \%$ & 0.882 & 0.378 \\
\hline
\end{tabular}

Notes: $n=397$. Response rate $41.1 \%$.

the US Census of Agriculture started collecting data on women farmers in 1978 (in itself an interesting fact, since data on race has been collected at least since 1900), the percentage of women principal operators has been steadily increasing. While the USDA now uses a more comprehensive definition of operator that recognizes that today's farms are often managed by more than one person (USDA NASS 2009), it is possible to construct a full time trend of women principal operators since 1978 showing female farmers on the rise (figure 3 ). Women now account for $30 \%$ of operators, up from $27 \%$ in 2002 (USDA NASS 2009). This indicates that women are becoming more important for agriculture at the national level. The time trend for the percentage of women principal operators in Iowa, as shown in figure 3, mirrors the national one. Though data on land ownership at the national level is very patchy-as Geisler and his coauthors noted in 1985, the Census of Agriculture "gives only secondary consideration to farmland ownership"-Geisler found that women increased the share of farmland they owned between 1946 and 1978 (Geisler et al. 1985). More recent data on ownership at the national level is not available. In Iowa, however, ownership data is collected via a regular Iowa State University survey, according to which women now own a majority of rented farmland and own or co-own just under half of overall farmland (Duffy and Smith 2008), while single women own a full fifth of the state's farmland (Clayton 2009). Despite this evidence of the growing importance of women in the agricultural sector, both in Iowa and nationally, government conservation programs and staff members are still not connecting with women, as Wells and Eells (2011) document.

\section{Figure 3}

Historical percentages of women principal operators in the United States and lowa.

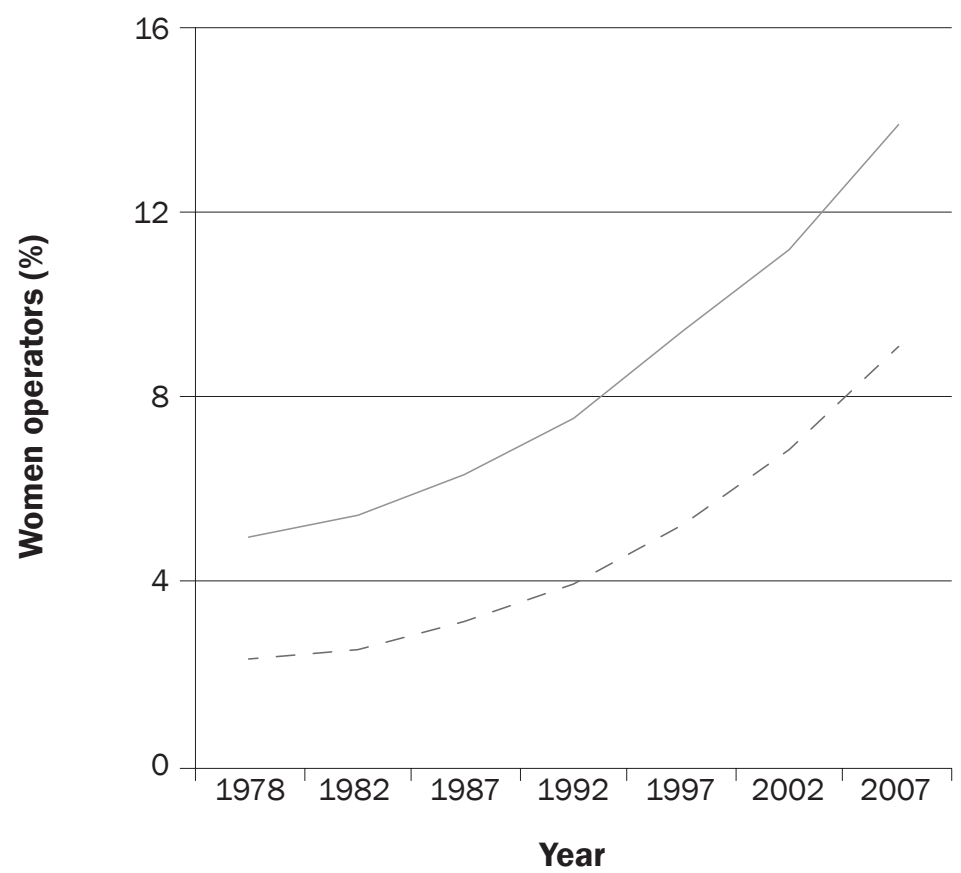

\section{Legend}

Women principal operators in United States

Women principal operators in lowa
Our research in the Clear Creek Watershed demonstrates that despite the long-term effort of a well-funded program supported by passionate conservation staff and local stakeholders, there is still a significant knowledge gap in the watershed. Female landowners and operators do not know as much about best management practices as their male counterparts, though our research suggests that they want to. These women may be even more receptive and willing to partner with public entities to improve conservation if better communication strategies and more concerted efforts are implemented.

Government conservation agencies might follow the lead of the Women Caring for the Land (WCL) program created by the Women, Food and Agriculture Network. Women Caring for the Land is a peer-topeer conservation education program that 
targets women landowners by inviting them to learning circles meant to foster a comfortable atmosphere for asking questions about conservation programs and practices. In the final report on the project, the WCL coordinator acknowledged that there is still a long way to go in improving outreach to female landowners. As she explained, "The comments and questions I heard [from participants] clearly indicated that much more conservation education is needed, both for women landowners and their tenants if we hope to change Iowa's landscape and improve our water quality" (Krouse 2009). Still, the program has had demonstrable success. Of the 45 women who participated in the 2009 pilot, half reported taking at least one conservation action within the following year (Eells and Adcock 2012). Peer-to-peer learning networks offer a strong option for improving conservation outreach to female landowners and operators. Our findings seem to confirm this: female (and male) landowners and operators in the Clear Creek Watershed look to neighbors and friends more than any other source for information about conservation. NRCS and county extension should continue their efforts to identify active landowners and farmers and recruit them to participate in and lead peer-to-peer education programs.

Government conservation organizations can also build from complementary research into extension efforts with women farmers (Liepins and Schick 1998; Brasier et al. 2009; Barbercheck et al. 2009) and research into the particular conservation needs and goals of women farmers (Trauger et al. 2008; Barbercheck et al. 2012), as well as research on the decision-making of women landowners (Wells and Eells 2011). Conservation staff should remember that familiarity breeds success-conservation staff who have more and closer contact with female farmers have a better understanding of their unique challenges and are better able to work successfully with them (Brasier et al. 2009; Barbercheck et al. 2009)-and that networking matters-women crave the opportunity to talk with, learn from, and teach other women (Barbercheck et al. 2009; Krouse 2009; Trauger et al. 2008). We applaud the efforts of the Iowa Department of Agriculture, NRCS, and County Conservation Districts in the Clear Creek Watershed to hold a women landowners meeting and emphasize farmerto-farmer networks. We wonder if these efforts were simply a matter of too little too late to gain traction in the watershed prior to our survey. Our sense is that it will take a focused and sustained effort to bring women into the conservation fold, but we think it can be done.

Women are a willing audience. And their favorable attitudes toward agricultural conservation and collaboration with government conservation staff suggest that they are an untapped resource that we can no longer afford to ignore. Our results indicate that women could be conservation staff's ideal audience, as they already overwhelmingly look to NRCS, county extension service, and FSA for information about conservation. Further research is needed to assess exactly why conservation information from these agencies is not connecting with them. Training and funding should be made available to allow and encourage conservation staff to alter their modes and methods of delivery and put sustained energy into better serving all agricultural landowners and operators.

\section{Acknowledgements}

The authors would like to begin by thanking James Martin, Regional Coordinator for the Iowa Department of Agriculture and Land Stewardship in Iowa City, Iowa, for his participation in and support of this project. Our survey would not exist without his involvement and support. We also want to thank Dave Bennett at the University of Iowa in Iowa City, Iowa, for his work on the creation of the survey, and Southern Illinois University Carbondale students Kent Rupp, Nigel Vorbrich, Mohamud Esmail, and Alison Britt in Carbondale, Illinois, for their hard work on the survey data entry. We thank the Clear Creek Watershed Enhancement Project, the Iowa and Johnson County Soil and Water Conservation Districts, the Iowa Department of Natural Resources (EPA 319 Program), the National Science Foundation (programs in Dynamics of Coupled Natural and Human Systems [Award 1114978], Cyber-Enabled Discovery and Innovation [Award 0835607], and Integrative Graduate Education and Research Traineeship [Award 0549245] administered through the Landscape, Ecological, and Anthropogenic Processes program at the University of Illinois at Chicago), the University of Illinois at Chicago, and AAUW for funding portions of this research.

\section{References}

Agbamu, J.U. 1995. Analysis of farmers' characteristics in relation to adoption of soil management practices in the Ikorodu area of Nigeria. Japanese Journal of Tropical Agriculture 39(4):213-222.

Arbuckle, J.G., Jr. 2010. Rented land in Iowa: Social and environmental dimensions. Ames, IA: Iowa State
University. http:// www.soc.iastate.edulextension/ farmpoll/PMR1006.pdf.

Arbuckle, J.G. Jr., P. Korsching, P. Lasley, and C. Kast. 2008. Iowa farm and rural life poll 2008 summary report. Ames, IA: Iowa State University. http://www.soc.iastate. edu/extension/ifrlp/PDF/PM2067.pdf.

Bannow, T. 2013. Meeting brainstorms how to clean Clear Creek Watershed. Iowa Press-Citizen. http://www.press-citizen.com/article/20130301/ NEWS01/303010025/Meeting-brainstorms-howclean-Clear-Creek-Watershed.

Barbercheck, M., K. Brasier, N.E. Kiernan, C. Sachs, and A. Trauger. 2012. Use of conservation practices by women farmers in the northeastern United States. Renewable Agriculture and Food Systems 1-18.

Brandth, B. 1994. Changing femininity: The social construction of women farmers in Norway. Sociologia Ruralis 34(2-3):127-149.

Brandth, B. 2002. Gender identity in European family farming. Sociologia Ruralis 42(3):181-200.

Brasier, K., M. Barbercheck, N.E. Kiernan, C. Sachs, A. Schwartzberg, and A. Trauger. 2009. Extension educators' perceptions of the educational needs of women farmers in Pennsylvania. Journal of Extension 47(3).

Carolan, M.S., D. Mayerfeld, M.M. Bell, and R. Exner. 2004 Rented land: Barriers to Sustainable Agriculture. Journal of Soil and Water Conservation 59(4):70A-75A.

Chiappe, M.B., and C. Butler Flora. 1998. Gendered elements of the alternative agriculture paradigm. Rural Sociology 63:372-393.

Clason, D.L., and T.J. Dormody. 1994. Analyzing data measured by individual Likert-type items. Journal of Agricultural Education 35:31-35.

Clay, D., T. Reardon, and J. Kangasniemi. 1998. Sustainable intensification in the highland tropics: Rwandan farmers' investments in land conservation and soil fertility. Economic Development and Cultural Change 45(2):351-378.

Clayton, M. 2009. Women lead a farming revolution in Iowa: As wives inherit husbands' farmland, they stress conservation over maximizing profit. Christian Science Monitor.http://www.csmonitor. com/Environment/Living-Green/2009/0225/ women-lead-a-farming-revolution-in-iowa.

Duffy, M. 2011. The current situation on farmland values and ownership. Choices: The Magazine of Food, Farm, and Resource Issues 26 (2). http:// www.choicesmagazine.org/choices-magazine/ theme-articles/farmland-values/the-current-situationon-farmland-values-and-ownership.

Duffy, M., and D. Smith. 2008. Farmland ownership and tenure in Iowa. 2007. PM 1983. Ames, IA: Iowa State University Extension. http://www.extension.iastate. edu/Publications/PM1983.pdf.

Eastwood, R., M. Lipton, and A. Newell. 2010. Farm size. In Handbook of Agricultural Economics, vol. 4, eds. P. Prabhu and R. Evenson, 3323-97. Oxford, UK: Elsevier. 
Eells, J., and L. Adcock. 2012. Women Caring for the LandSM: Improving conservation outreach to female non-operator farmland owners. Ames, IA: Women, Food and Agriculture Network. http://www.wfan.org/ Women_Caring_files/WCLManualForWeb3-12.pdf.

Everett, B.B. 1983. Viewpoint: Soil conservation: A farm women's perspective. Journal of Soil and Water Conservation 38(2):69.

Feldman, S., and R.Welsh. 1995. Feminist knowledge claims, local knowledge, and gender divisions of agricultural labor: Constructing a successor science. Rural Sociology 60:23-43.

Fuglie, K.O. 1999. Conservation tillage and pesticide use in the cornbelt. Journal of Agricultural and Applied Economics 31(1):133-147.

Geisler, C.C.,W.F.Waters, and K.L.Eadie. 1985.The changing structure of female agricultural land ownership, 1946 and 1978. Rural Sociology 50(1):74-87.

Hassanein, N. 1999. Changing the Way America Farms: Knowledge and Community in the Sustainable Agriculture Movement. Lincoln, NE: University of Nebraska Press.

Iowa Department of Natural Resources. 2008. Soils Requiring Tile Drainage for Full Productivity. Iowa Geological and Water Survey, DNR, Iowa City, Iowa. ftp://ftp.igsb.uiowa.edu/gis_library/ia_state/ agriculture/tiled_soils/tiled_soils.zip.

Iowa Department of Natural Resources. 2012. Animal Feeding Operations Listed in the Iowa Department of Natural Resources' Animal Feeding Operations Database. Iowa Geological and Water Survey, DNR, Iowa City, Iowa. ftp://ftp.igsb.uiowa.edu/gis_library/ ia_state/agriculture/animal_feeding_operations.zip.

Iowa Department of Natural Resources Watershed Improvement Division. 2007. Total Maximum Daily Loads for Pathogen Indicators, Iowa River, Johnson County, Iowa. Des Moines, IA: Iowa Department of Natural Resources. http://www.epa.gov/waters/ tmdldocs/33135_IOWA\%20TMDL.pdf.

Kauffman, N. 2012. Will farm profits shift in 2013? Main Street Economist 6. Kansas City, MO: Federal Reserve Bank of Kansas City. http://www.kansascityfed.org/ publicat/mse/MSE_0612.pdf.

Key, N.D., W.D. McBride, M. Ribaudo, and S. Sneeringer. 2011. Trends and developments in hog manure management: 1998-2009. US Department of Agriculture, Economic Research Service

Knowler, D., and B. Bradshaw. 2007. Farmers' adoption of conservation agriculture: A review and synthesis of recent research. Food Policy 32:25-48.

Krouse, L. 2009. Final report for Women Caring for the Land. Ames, IA: Women, Food and Agriculture Network. http://www.wfan.org/Women_Caring_files/final $\% 20$ report,\%20May,\%202009.doc.

Liepins, R., and R. Schick. 1998. Gender and education: Towards a framework for a critical analysis of agricultural training. Sociologia Ruralis 38:285-302.
Marra, M.C., and B.C. Ssali. 1990. The role of human capital in the adoption of conservation tillage: the case of Aroostook County, Maine, potato farmers. Maine Agricultural Experiment Station Bulletin 831:iii-37.

Meares, A.M. 1997. Making the transition from conventional to sustainable agriculture: Gender, social movement participation, and quality of life on the family farm. Rural Sociology 62(1):21-47.

Neill, S.P., and D.R. Lee. 2001. Explaining the adoption and disadoption of sustainable agriculture: The case of cover crops in northern Honduras. Economic Development and Cultural Change 49(4):793-820.

Nowak, P.J. 1987. The adoption of agricultural conservation technologies: Economic and diffusion explanations. Rural Sociology 52(2):208-220.

Okoye, C. 1998. Comparative analysis of factors in the adoption of traditional and recommended soil erosion control practices in Nigeria. Soil and Tillage Research 45:251-263

Osteen, C., J. Gottlieb, and U. Vasavada. 2012. Agricultural Resources and Environmental Indicators Washington, DC: USDA Economic Research Service. http://www. ers.usda.gov/media/874175/eib98.pdf.

Pautsch, G.R., L.A. Kurkalova, B.A. Babcock, and C.L. Kling. 2001. The efficiency of sequestering carbon in agricultural soils. Contemporary Economic Policy 19(2):123-134.

Peter, G., M. Mayerfeld Bell, S. Jarnagin, and D. Bauer. 2000. Coming back across the fence: masculinity and the transition to sustainable agriculture. Rural Sociology 65:215-233

Prokopy, L.S., K. Floress, D. Klotthor-Weinkauf, and A. Baumgart-Getz. 2008. Determinants of agricultural best management practice adoption: Evidence from the literature. Journal of Soil and Water Conservation 63(5):300-311 doi:10.2489/jswc.63.5.300.

Rahm, M.R., W.E. Huffman. 1984. The adoption of reduced tillage: The role of human capital and other variables. American Journal of Agricultural Economics 66(4):405-413.

Salamon, S. 1992. Prairie Patrimony: Family, Farming, and Community in the Midwest. Chapel Hill, NC: University of North Carolina Press.

Saltiel, J., J.W. Bauder, and S. Palakovich. 1994. Adoption of sustainable agricultural practices: Diffusion, farm structure and profitability. Rural Sociology 59(2):333-349.

Shortle, J.S., and J.A. Miranowski. 1986. Effects of risk perceptions and other characteristics of farmers and farm operations on the adoption of conservation tillage practices. Applied Agricultural Research 1(2):85-90.

Smit, B., and J. Smithers. 1992. Adoption of soil conservation practices: an empirical analysis in Ontario, Canada. Land Degradation and Rehabilitation 3(1):1-14

Soenen, B. 2008. The power of one: The Clear Creek story. The Volunteer Monitor 19(1):18-20.

Somda, J., A.J. Nianogo, S. Nassa, and S. Sanou. 2002. Soil fertility management and socio-economic factors in crop-livestock systems in Burkina Faso: A case study of composting technology. Ecological Economics 43:175-183.

Soule, M.J., A. Tegene, and K.D. Wiebe. 2000. Land tenure and the adoption of conservation practices. American Journal of Agricultural Economics 82(4):993-1005.

Swinton, S.M. 2000. More social capital, less erosion: evidence from Peru's Antiplano. Paper presented at the American Agricultural Economics Association Annual Meeting, Tampa, FL, July 30-August 2, 2000. http://www.biw. kuleuven.be/aee/clo/idessa_files/Swinton2000.pdf.

Trauger, A., C. Sachs, M. Barbercheck, N. E. Kiernan, K. Brasier, and J. Findeis. 2008. Agricultural education: Gender identity and knowledge exchange. Journal of Rural Studies 24(4):432-439.

Trauger, A., C. Sachs, M. Barbercheck, N.E. Kiernan, K. Brasier, and A. Scwartzberg. 2010. The Object of Extension: Agricultural Education and Authentic Farmers in Pennsylvania. Sociologia Ruralis 50(2):85-103.

USDA National Agricultural Statistics Service (NASS). 2009. 2007 Census of Agriculture Women farmers. http:// www.agcensus.usda.gov/Publications/2007/Online_ Highlights/Fact_Sheets/Demographics/women.pdf.

USDA National Agricultural Statistics Service (NASS), Research and Development Division). 2010. Cropland Data Layer. http://www.nass.usda.gov/research/ Cropland/SARS1a.htm.

USDA Natural Resources Conservation Service (NRCS). 2012. Johnson County EQIP. http://www.nrcs.usda. gov/wps/portal/nrcs/detail/ia/programs/financial/ eqip/?cid=nrcs142p2_008029.

United States Environmental Protection Agency (USEPA). 2012. Section 319. Nonpoint Source Program Success Story, Iowa. Multi-Agency Effort Cleans Up Clear Creek. 841-F-12-001PP. http://water.epa.gov/ polwaste/nps/success319/upload/ia_clear.pdf.

Uri, N.D. 1997. Conservation tillage and input use. Environmental Geology 29(3/4):188-201.

Warriner, G.K., and T.M. Moul. 1992. Kinship and personal communication network influences on the adoption of agriculture conservation technology. Journal of Rural Studies 8(3):279-291.

Wells, B., and J. Eells. 2011. One size does not fit all: Customizing conservation to a changing demographic. Journal of Soil and Water Conservation 66(5):136A-139A doi:10.2489/jswc.66.5.136A 